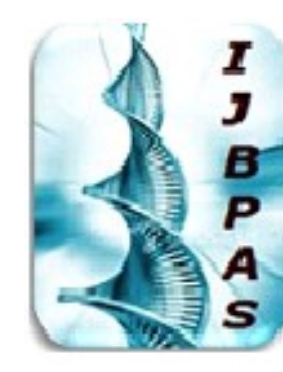

International Journal of Biology, Pharmaey and Allied Sciences (IJBPAS)

'A Bridge Betueen Caboratory and QRendo'

\title{
WwW.iibpas.com
}

\section{A STUDY ON AMYLASE: REVIEW}

\section{JOSHI ${ }^{1}$, ANDHARE $\mathrm{P}^{2}$, MARCHAWALA $\mathrm{F}^{2}$, BHATTACHARYA $\mathrm{I}^{2}$ AND UPADHYAY $\mathbf{D}^{2 *}$}

1: Student, MSc Microbiology, Parul Institute of Applied Sciences, Parul University, Post Limda, Waghodia, Gujarat, 391760

2: Assistant Professor, Parul Institute of Applied Sciences, Parul University, Post Limda, Waghodia, Gujarat, 391760

*Corresponding Author: Dr. Dhwani Upadhyay; E Mail:dhwani.updhyay82123@paruluniversity.ac.in;

Tel: +919558021474

Received 22 ${ }^{\text {nd }}$ Jan. 2021; Revised 24 ${ }^{\text {th }}$ Feb. 2021; Accepted $25^{\text {th }}$ March 2021; Available online $1^{\text {st }}$ April 2021 https://doi.org/10.31032/IJBPAS/2021/10.4.1037

\section{ABSTRACT}

Amylase is an enzyme that breaks down the starch into dextrin and smaller polymers composed of glucose molecules. This enzyme is derived from plants, animals and microorganisms. Among microorganisms, fungal and bacterial amylases are commonly used. Amylase usually an extracellular enzyme. Three types of microbial amylases are there: alphaamylase, beta-amylase and gamma-amylase. They all have a different way for acting on starch to obtain simple glucose monomers. The industrial production of amylase is carried out using 2 methods: Submerged fermentations and solid state fermentations. The important factors that affect the fermentation process are $\mathrm{pH}$, temperature, carbon and nitrogen sources, and metal ions. Amylases are one of the most essential and widely used enzymes in number of industries, including food, fermentation, paper, textile and pharmaceutical industries.

In this review, the structure, types, microbial sources and applications of amylases have been studied.

Keywords: Enzymes, amylases, history of amylases, sources of amylases \section{INTRODUCTION}

Enzymes are biological compounds that act as catalyst, which accelerate biochemical and biological reactions. They were discovered in the second-half of the nineteenth century [1]. They are highly specific in their structure. They have an 
active site to which substrate molecule binds and converts into a product [2]. Enzymes are produced by animals, plants and microbes. From these, microbial enzymes are of great importance because they are more economic to produce and stable. Among all the microbial enzymes, amylase is a very common enzyme that is used [3].

Amylase is also known as 'glycoside hydrolase'. Amylases have a vial function in the starch. Amylases act on $\alpha-1,4$ and $\alpha$ $-1,6$ glycosidic linkages present in starch and glycogen, a starch-related polysaccharide [4]. They catalyze the hydrolysis of starch molecules into sugars such as maltose and dextrins, as well as smaller polymers made up of glucose units [5]. Starch is non-aromatic, white-coloured and granular polysaccharide which is composed of amylose (20-30\%) and branched amylopectin (70-80\%) along with the small amount of phosphate and lipids [6].

Kirchhoff discovered the first starch degrading enzyme in 1811, which was followed by studies of digestive amylases and malt amylases. In 1930, Ohlsson proposed the groups of starch digestive enzymes in malt as alpha and beta amylases based on the anomeric form of sugars generated by the enzyme reaction [7].

Amylase enzymes are widely distributed in microbes including fungi and bacteria. For the production of amylases, the most commonly used bacteria is Bacillus. Species like B. subtilis, B. licheniformis, $B$. amyloliquefaciens are good producers of amylase enzyme. Among the fungi, filamentous fungi are widely used in the amylase production. Fungi belonging to the genus Aspergillus have been widely used for the production of alpha amylase [8]. Amylases which are produced by an organisms are classified into Exoenzymes and Endoenzymes. The enzymes which are released from the cell and act on the substrate are known as exoenzymes. The enzymes which are utilized by the cell and mainly responsible for synthesis are known as endoenzymes [9]. Three types of amylases are there: alpha amylase, beta amylase and gamma amylase. $\alpha$-amylases act at random locations along the starch chain and breakdown long-chain carbohydrate. $\beta$-amylases act from the nonreducing end and catalyze the hydrolysis of the second $\alpha-1,4$ glycosidic bond, cleaving off two glucose units at a time. $\gamma$-amylases act from the non-reducing end and cleave last $\alpha-1,4$ glycosidic linkages, yielding glucose with $\alpha(1-6)$ glycosidic bond [10].

Methods used for the production of amylase are Submerged fermentation (SmF) and Solid-statefermentation (SSF). In submerged fermentations, free-flowing liquid substrates such asmolasses and broths are applied. The end products are 
released into the fermentation broth. Insolid-state fermentations, bran and paper pulp are used as substrate, which are nutrient-richwaste materials. It is promising method for commercial enzyme production [11]. The amylase production by fermentation is affected by some nutritional factors such as nitrogenand carbon sources, metal ions, and physicochemical factors like $\mathrm{pH}$, inoculum age, inoculums concentration, agitation, incubation temperature and incubation time [12].

Amylases are used in a wide range of industries, including food, textiles, detergents, paper, and pharmaceuticals [13].

\section{HISTORY OF AMYLASE}

Amylase is one of the oldest enzymes known. In 1815, the history of amylase was initiated when the first starch degrading enzyme was discovered by Kirchhoff. He conducted an experiment in which he combined four parts water, two parts starch, and one part malt to make a starch paste that began to liquefy into a sweet syrup.His result demonstrated that gluten had the capability toconvert a starch into sugar. In 1831, Erhard Friedrich Leuchs explained that saliva contains an enzyme called "ptyalin," which is an amylase that aids in the hydrolysis of starch [7].

\section{MICROBIAL SOURCE OF AMYLASES}

Amylase enzyme is produced by plants, animals and microbes. Despite the fact that amylases can be made from a variety of sources, microbial amylases are the most common and widely used in industry due to their thermostability and productivity [14]. Amylases derived from bacteria and fungi are commonly employed in a number of industries due to advantages such as cost effectiveness, consistency and less time required for production [15]. Among bacteria, Bacillus species is widely used for amylase production. B. subtilis, B.licheniformis and B. amyloliquefaciens are refered as the good producers of amylase. Filamentous fungi are widelyemployed for the production of amylase. Among fungi, Aspergillus and Rhizopus species are widely exploited for the production of amylase [16].

\section{CLASSIFICATION OF AMYLASES}

Amylases can be categorized into two classes on the basis of their mode of action, endoamylases and exoamylases [17]. Endoamylases cleave $\alpha-1,4$ glycosidic bonds between adjoining glucose units present in the starch chain [18]. Exoamylases either catalyze the cleavage of $\alpha-1,4$ glycosidic bond or catalyze the cleavage of both $\alpha-1,4$ and $\alpha-1,6$ glycosidic linkages like glucoamylase and $\alpha$ glycosidase [19].

\section{STRUCTURE OF AMYLASES}

Amylases have a 3D structure, having ability to binding to the substrate and promote the breakage of the glycoside 
bonds by the action of catalytic groupsthat are highly specific [20]. The protein contains three domains: A, B and C. The A domain is the largest, having a typical barrel shaped structure. The B domain is introduced between $\mathrm{A}$ and $\mathrm{C}$ domain and bound to A domain by disulphide bond. The $\mathrm{C}$ domain has a $\beta$ sheet structure attached to the A domain by a simple polypeptide chain.It appears to be a separate domain with an unknown function. The active site of alpha amylase which is also known as'substrate binding site' is located in a long cleft situated between the carboxyl end of the A and B domains [21].

\section{TYPES OF AMYLASES}

Amylases can be classified into three types on the basis of the cleavage site: $\alpha$-amylase, $\beta$-amylase and $\gamma$-amylase.

\section{$\alpha$-amylases:}

Alpha- amylases are calcium metalloenzymes that are unable to act when calcium is not there. Alpha-amylases are an example of endoamylases [22]. They breakdownthe internal $\alpha-1,4$ glycosidic bonds present in the starch chain to produce products like maltotriose and maltose from amylose or maltose, glucose and "limit dextrin" from amylopectin [18].

\section{$\beta$-amylases:}

$\beta$-amylases hydrolyze the second $\alpha-1,4$ glycosidic linkage, producing two glucose units. Beta-amylases are an example of exoamylases. During the ripening of fruit, these enzymes breakdown starch into sugar and result is sweetening of ripe fruit [5].

\section{$\gamma$-amylases:}

It is also known as glucoamylase. They catalyze hydrolysis of $\alpha-1,4$ and $\alpha-1,6$ glycosidic bonds. While comparing to other types of amylases, $\gamma$-amylase is the most effective enzyme in acidic environments [23].

\section{PROPERTIES OF AMYLASES}

pH:

Among the physical properties, the $\mathrm{pH}$ performs an essential role by inducing morphological change in the organism as well as in the enzyme secretion. $\mathrm{pH}$ value is an significant indicator of the initiation and end of the process of production of enzyme [24]. Alpha-amylases are usually stable over a wide range of $\mathrm{pH}$ from 4 to 11 [25].

\section{Temperature:}

The effect of temperature on the production of amylase is linked to the microbe's growth. It is desirable that alpha amylase should be active at high temperature of liquefaction $\left(80-90{ }^{\circ} \mathrm{C}\right)$ and gelatinization $\left(100-110{ }^{\circ} \mathrm{C}\right)$ to economize the process; therefore more thermophilic and thermostable $\alpha$-amylases are required. Majority of amylases have a temperature range of $30{ }^{\circ} \mathrm{Cto} 100{ }^{\circ} \mathrm{Cas}$ their optimum temperature [26]. 


\section{APPLICATIONS OF AMYLASES}

\section{Liquefaction:}

In this process, insoluble starch granules present in the aqueous solution are dispersed by partial hydrolysis using thermostable amylases. Thermostable $\alpha$ amylase is employed as a thinning agent to reduce the viscosity and partial hydrolysis of starch [27].

\section{Textile industry:}

Alpha-amylases are used in the textile industry to hydrolyze and solubilize starch, which is then washed out of the fabric to improve the stiffness of the finished product. Alpha amylase is used as desizing agent to remove the starch from the grey cloth before further its processing like bleaching and dyeing [21].

\section{Bread industry:}

Enzymes like malt and fungal alphaamylase have been employed in breadmaking. Using the enzymes in the flour improves the bread's flavour, fragrance, quantity, and porosity [3].

\section{Detergent industry:}

Enzymes are used in detergents formulations to increase the ability of detergents in order to remove tough stains. Among liquid detergents, 90\% detergents contain amylases. Amylases used in this industries are mainly derived from Bacillus or Aspergillus [10].

\section{CONCLUSION}

Amylase catalyzes the reaction of conversion of starch into sugar. Amylase was discovered in 1815 by Kirchhoff. Amylase is obtained from plants, animals and microorganisms. Amylase that is produced by microbes being economically easy to manipulate, more controllable and more stable than the enzymes obtained by plants and animals. Amylases have played an important role in different industrial processes such as in detergent industry, paper industry, food industry and pharmaceutical industry.

\section{ACKNOWLEDGEMENT}

It's our privilege and honour to express our sincerest gratitude to the Parul University, Vadodara, Gujarat for providing me all the necessary support and facilities including state of the art infrastructural facilities with advanced technological scientific laboratories and everything else that was required to carry out this work

\section{REFERENCES}

[1] Panneerselvam, T., and S. Elavarasi. Isolation of $\alpha$-amylase producing Bacillus subtilis from soil. International journalof current microbiology andapplied sciences. 2015; 4(2): 543-552.

[2] Vitolo Michele. Brief review on enzyme activity. World Journal of Pharmaceutical Research. January 2020; 9(2): 60-76. 
[3] John Jinu. Amylases-bioprocess and potential applications: a review. International Journal of Bioinformatics and Biological Sciences. December 2017; 5(2): 4150.

[4] Nisha Mohanan and Tulsi Satyanarayana. Amylases. Elsevier. 2018.

[5] RaniKirti, Rachna Rana et al; Review on characteristics and application of amylases. International journal of microbiology and bioinformatics. January 2015; 5(1): $1-5$.

[6] Isha Kohli, Naveen Chandra Joshi et al; Production, purification and applications of raw starch degrading and calcium-independent $\alpha$-amylase from soil rich in extremophile. International journal of biological macromolecules. June 2020; 162: 873-881.

[7] Oluwadamilare, L. A., Oluwatofunmi et al; A review of literature on isolation of bacteria $\alpha$ amylase. International Research Journal of Engineering and Technology. February 2019; 6(1).

[8] Rehman Aneela and Asma Saeed. Isolation and screening of amylase producing Bacillus species from soil. International journal of advanced research. March 2015; 3(4): 151-164.

[9] Padma Singh and Pallavi Kumari. Isolation and characterization of amylase producing Bacillus spp. from selected soil sample. International Journal of Research in Biosciences. April 2016; 5(2): 2429.

[10] Indrakshi Bhattachearjee, Deepika Mazumdar et al; Microbial amylases and their potential application in industries: A review. The pharma innovation journal. May 2019; 8(6): 162-170.

[11] Suriya, J., S. Bharathiraja et al; Marine microbial amylases: properties and applications.Advances in food and nutrition research. 2016; 79: 161177.

[12] Sales, Paloma Michelle et al; $\alpha$ Amylase inhibitors: a review of raw material and isolated compounds from plant source. Journal of Pharmacy \& Pharmaceutical Sciences. 2012; 15(1): 141-183.

[13] Fentahun Mengistu and Pagadala Vijaya Kumari. Isolation and screening of amylase producing thermophilic spore forming Bacilli from starch rich soil and characterization of their amylase 
activity. African Journal of

Microbiology Research. June 2017; 11(21): 851-859.

[14] Fossi, Bertrand Tatsinkou et al; Production and partial characterization of a thermostable amylase from ascomycetes yeast strain isolated from starchy soils. African Journal of Biotechnology. January 2005; 4(1): 14-18.

[15] Swetha Sivaramakrishnan, Gangadharon Dhanya et al; $\alpha$ Amylases from Microbial Sources-An Overview on Recent Developments. Food Technol Biotechnol. March 2006; 44(2): 173-184.

[16] Martin, M. F, Ekomobong Okpo et al; Microbial amylases: A review. World News of Natural Sciences: An International Scientific Journal. June 2019; 22: 174-179.

[17] Ahmad, M. A., U. Isah et al; An overview of the enzyme: Amylase and its industrial potentials. Bayero Journal of Pure and Applied Sciences. November 2019; 12(1): 352-358.

[18] Madhavi Nimavat andDarshan Marjadi. Analysis of amylase production from different substrate. International Journal of
Trend in Scientific Research and Development. April 2018; 2(3).

[19] Neerja Rana, Abhishek Walia et al; $\alpha$-Amylases from microbial sources and its potential applications in various industries. National Academy Science Letters. December 2012; 36(1): 9-17.

[20] Souza, Paula Monteiro de. Application of microbial $\alpha$ amylase in industry-A review. Brazilian journal of microbiology. May 2010. 41(4): 850-861.

[21] S. P. Tiwari, R. Srivastava et al; Amylases: an overview with special reference to alpha amylase. Journal of global bioscience. January 2015; 4: 1886-1901.

[22] Ullah Irfan, Mohammad Sayyar Khan et al; Identification and characterization of thermophilic amylase producing bacterial isolates from the brick kiln soil. Saudi journal of biological sciences. November 2020; 28(1): 970-979.

[23] Annisyia Zarina Putri and Tomoyuki Nakagawa. Microbial $\alpha$-Amylases in the Industrial Extremozymes. Reviews in Agricultural Science. August 2020; 8: 158-169. 
[24] Rani Gupta, Paresh Gigras et al;

Microbial $\quad \alpha$-amylases: a

biotechnological

perspective. Process biochemistry.

October 2003; 38(11): 1599-1616.

[25] N. S. Reddy, Annapoorna

Nimmagadda et al; An overview

of the microbial $\alpha$-amylase

family. African Journal of

Biotechnology.November 2003;

2(12): 645-648.

[26] Nisha Kumari, Babita Rani Sushil et al; Microbial amylases: An overview on recent advancement. Journal of Entomology and Zoology Studies. December 2018; 7(1):198-205.

[27] Aiyer Prasanna V. Amylases and their applications. African journal of biotechnology. September 2005; 4(13): 1525-1529. 